\title{
INTRODUCING LIFE MAPS AS TECHNIQUE IN A SOCIAL GROUP WORK PROGRAMME FOR YOUNG ADULTS LIVING WITH HIV/AIDS
}

\section{H Strydom, AG Herbst}

\section{LITERATURE REVIEW}

\section{Background}

The first literature regarding life maps was found in a philosophy textbook dated 1909. The focus of this book was the individual's life (the map of life) and the correlation with happiness and contentment throughout one's life span. This book indicated many links with life maps as described in this study. The following interesting topics (Lecky, 1909) are worth mentioning:

- Happiness is a condition of the mind;

- Contentment and the desire for progress and self-growth should be balanced;

- Life actions should be guided;

- There is an ending to life - namely death.

The map of life could describe one's being from birth to death, emphasising different events, people, attitudes, choices, problems/difficulties and biological processes.

\section{Description}

Life maps are described as a tool for self-discovery, taking the individual through his/her life from birth to death, dealing with the self, significant others, obstacles, choices, beliefs and the future. (Mulligan, 1988:12) describes life maps as follows:

"Life maps are tools for self-discovery, and guides to various aspects of your life as you experience it. They are a way of outlining the territory, signposting the terrain and becoming familiar with the landscape of your life. Maps can help you connect up the various aspects of your life by establishing links between your past, present and future, and the different levels of your being, for example, your mind, body, emotions and spirit. They can help you focus on the detail of specific areas of your life."

According to Yochanan (1991), life maps can meet various aims of a group work programme, which includes defining the problem, determining goals, collecting information, developing alternatives and evaluating outcomes. Herbst (2002:128) summarised and integrated the previous descriptions in order to formulate the following description: "Life maps are an assessment and therapeutic technique to guide individuals or groups to review their lives in terms of the past, present and future by focusing on their own views of themselves, others, their problems and coping skills".

\section{Related Techniques}

Life maps may be linked to similar techniques such as life stories (McCormick, 1996), life scripts (Retief, 1999), magazine photo collages (Landgarten, 1993), and life mapping (Heppner, O'Brien, Hinkelman \& Humphrey, 1994). It is necessary to distinguish clearly between life mapping and life maps. Life mapping involves the listing of important people or events on pieces of paper. After having listed them, the client arranges them on a large piece of paper in a way that is meaningful to him/her. Important connections and influences can then be illustrated and used for discussion. Life maps, on the other hand, guide the individual on a journey through his/her life by focusing on the following seven questions: 
- WHO AM I? (Life Map 1)

- WHERE HAVE I COME FROM? (Life Map 2)

- WHERE AM I GOING? (Life Map 3)

- WHAT IS STOPPING ME? (Life Map 4)

- HOW WILL I GET THERE? (Life Map 5)

- WHAT HELP DO I NEED? (Life Map 6)

- WHAT WILL IT BE LIKE WHEN I GET THERE? (Life Map 7)

Answers to the seven questions may be formulated in various creative ways, including writing, painting, drawing, clay sculpting, music, dancing or photo collages. From the author's point of view, the most important aspect of this technique is that it does not stop with the past. It guides the individual to link the past to the present, but most importantly, urges the individual to focus on personal strengths and the future.

The following figure is a summary of the differences and similarities between life maps and related techniques.

\section{FIGURE 1}

SUMMARY OF TECHNIQUES RELATED TO LIFE MAPS

\begin{tabular}{|l|l|l|l|}
\hline \multicolumn{1}{|c|}{ LIFE STORIES } & \multicolumn{1}{|c|}{ LIFE SCRIPTS } & \multicolumn{1}{c|}{ COLLAGES } & \multicolumn{1}{c|}{ LIFE MAPS } \\
\hline $\begin{array}{l}\text { Technique for } \\
\text { assessment and self- } \\
\text { expression }\end{array}$ & $\begin{array}{l}\text { Technique for } \\
\text { assessment and self- } \\
\text { expression }\end{array}$ & $\begin{array}{l}\text { Technique for } \\
\text { assessment and self- } \\
\text { expression }\end{array}$ & $\begin{array}{l}\text { Technique for } \\
\text { assessment and self- } \\
\text { expression }\end{array}$ \\
\hline Mainly unstructured & Semi-structured & Structured & $\begin{array}{l}\text { Structured, but } \\
\text { flexible }\end{array}$ \\
\hline Focus on the past & Focus on the past & $\begin{array}{l}\text { Focus on the past, } \\
\text { present and future }\end{array}$ & $\begin{array}{l}\text { Focus on the past, } \\
\text { present and future }\end{array}$ \\
\hline $\begin{array}{l}\text { Clearly defined } \\
\text { emotional impact }\end{array}$ & $\begin{array}{l}\text { More philosophical } \\
\text { impact }\end{array}$ & $\begin{array}{l}\text { The impact is } \\
\text { determined by the } \\
\text { individual's own } \\
\text { perceptions }\end{array}$ & $\begin{array}{l}\text { The impact is both } \\
\text { emotional and } \\
\text { practical, allowing the } \\
\text { individual to develop } \\
\text { life skills }\end{array}$ \\
\hline $\begin{array}{l}\text { The individual needs } \\
\text { to be literate to utilise } \\
\text { this technique }\end{array}$ & $\begin{array}{l}\text { The individual needs } \\
\text { to be literate to utilise } \\
\text { this technique }\end{array}$ & $\begin{array}{l}\text { Can be administered } \\
\text { to persons from any } \\
\text { group }\end{array}$ & $\begin{array}{l}\text { Can be administered } \\
\text { to persons from any } \\
\text { group }\end{array}$ \\
\hline
\end{tabular}

(Herbst, 2002:131)

\section{Theoretical foundation}

This technique originated from an existential perspective. In order to place the life map technique in a theoretical perspective, it is necessary to define existential social work. Barker (2003:150) defines existential social work as:

"A philosophical perspective in social work that accepts and emphasises the individual's fundamental autonomy, freedom of choice, disillusionment with prevailing social mores, a sense of meaning derived from suffering, the need for dialogue and the social worker's commitment to the concept of client self-determination." 
Existential social work can be seen as the basic theoretical framework of this study, including components of a number of other theories. With reference to the self-actualisation theory of Abraham Maslow, much emphasis is placed upon the principles of needs fulfilment, the individual's active will to grow and the importance of utilising existing potential within the individual (Herbst \& De la Porte, 2006). The individual's search for meaning and need for emotional and spiritual growth are further explored through the existential theory of Viktor Frankl (Shantall, 1988). The concept of holism is mentioned in most of these theories, but is best described by the gestalt theory of Fritz Perls (Biggs, 1994; Gilliand, James, Roberts \& Bowman, 1984). Moreover, key aspects of the reality theory of William Glasser that are deemed important include reality, respect, responsibility, right and wrong and recognition (Herbst \& De la Porte, 2006). The narrative theory of Michael White and David Epston can be seen as a meta-code for the search for meaning by creatively reflecting upon the stories of people's lives (Dulwich Centre, 2002; Herbst \& De la Porte, 2006; Van Niekerk, 2003). All of the abovementioned theories may be summarised in Patel's (2005:206) description of the strengths perspective as "the practical and appropriate application of knowledge, skills and values to enhance the well-being of individuals, families, groups, organisations and communities in their social context". Furthermore, Van Wormer and Davis (2003:67) refer to Saleebey's lexicon of strengths as the principles of the strengths perspective. The following aspects are particularly important in the life map technique:

- The empowerment of individuals and communities;

- Membership or belongingness;

- Resilience;

- Healing;

- Wholeness;

- Dialogue and collaboration;

- The suspension of disbelief in the client's words, thoughts and feelings.

Arguments from the afore-mentioned theories were integrated to develop an existential approach to this group work programme. Existential group work is based on the individual's freedom to choose, taking responsibility for one's choices and circumstances, exploration of meaning, guiding individuals to consider who they are so they can pursue direction in life, and empowering individuals to make well-informed choices (Corey, 1995; Herbst, 2002). Although existential groups were not described as a specific kind of group, the researcher used an existential viewpoint when planning the group work programme based on the following two arguments: suffering and illness (such as HIV/AIDS) are a normal part of life; and the true meaning of life is a process of searching. Clarkson and MacKewn (1993:44-46; 341-346) suggest consideration of the following values in existential work:

- Creative values - the things one can add to life by finding meaning in one's work or involvement with others;

- Values of awareness - the values one receives from life concerning what is good, real and beautiful. This includes love and commitment;

- Values of attitude - the way one looks at life and one's attitude towards suffering;

- The tragic triad of pain, guilt and death, which are crucial aspects one has to deal with in life, and which emphasise the fact that one's attitude towards these aspects will determine one's experience of meaning in life; 
For optimal development, one needs the following:

- Self-determined behaviour;

- Realistic observation;

- Humour;

- Self-transcendence;

- An active futuristic attitude;

- Seeing work as a calling;

- Appreciation of the good, truth and aesthetics;

- Respect for others' uniqueness;

- Finding meaning in suffering and pain.

According to Corey (1995) these aspects may be applied to existential group work in order to empower individuals to undertake a lifelong journey of self-exploration with specific goals in mind, such as:

- Becoming honest with oneself;

- Obtaining new perspectives on the self and the world around the self;

- Defining meaning in the present and future;

- Basic human needs include the need to love and receive love and to feel valued by oneself and others. Successful attainment of these needs leads to a successful identity and healthy selfesteem;

- The moral issue of right and wrong is a key focus area of the theory;

- The focus is on learning, rather than on healing;

- The main goal is self-awareness, including knowledge of the environment, taking responsibility for choices, self-knowledge, self-acceptance and the ability to make contact with the inner self;

- The here and now are very important - what the client experiences at the moment and how he/she behaves currently, emphasising the fact that the past and future are continuously linked to the present;

- The person is seen as a total organism, not just as a brain;

- Awareness is very important, implicating the individual's ability to be in touch with his/her whole perceptual field within the self, the environment, emotions, behaviour, experiences and incompleteness within the self (Biggs, 1994; Clarkson \& MacKewn, 1993; Gilliand et al., 1984; Thompson \& Rudolph, 1992).

Who am I? is the question asked in Life Map 1. This question focuses on the concept of identity. According to Whitbourne (1986), the process of identity assimilation and identity accommodation is crucial to achieve a state of equilibrium, as is described by gestalt theory. Selfknowledge and self-awareness are the essence of existentialism and the basis for finding meaning and purpose in life. Awareness is also important, according to the gestalt theory. Johnson (1990:63) describes identity as "a consistent set of attitudes that defines who you are". Without identity, the individual will be anxious and depressed, and there will be a lack of contentment and self-growth. The question Who am I? is crucial. Without this question, no inner process in human beings has a starting point. The questions in Life Map 1 also contribute towards selfdetermination, personal responsibility, overcoming fears, feelings, obstacles, confusion and 
existential anxiety. While redefining the past and one's background, the map offers opportunities for resolving conflicting relationships, utilising personal, social and community resources, exploring and developing skills and strengths, emotional disclosure, problem solving, dealing with losses, gaining control, providing a clear vision of how things are and how they have been, determining the changes one would like to make and how one could begin to achieve them (Corey, 1995; Johnson, 1990; McCormick, 1996; Shaffer \& Galinsky, 1989).

\section{THE ADVANTAGES AND DISADVANTAGES OF LIFE MAPS}

\section{Advantages}

- The individual's past, present and future can be integrated.

- The individual experiences control over his/her own life.

- The individual gains access to his/her own life story, while providing answers and resolving misconceptions and confusion.

- Life maps give a clear indication of how things are and how they have been.

- They provide continuity and assist the individual to develop an intact sense of identity.

- The individual's expression through this medium becomes the document that gains access to conscious as well as unconscious material.

- It is a flexible instrument that can be used for illiterate people from any culture.

- Due to specific themes, the technique is task oriented.

- Life and coping skills may be explored and learnt.

- The individual can make alterations and adjustments to his/her life.

- Life maps can generate interest and create enthusiasm for life.

- Life maps allow freedom of expression and can guide the individual to overcome emotional blockages such as anger and guilt.

(Backhaus, 1984; Landgarten, 1993; McCormick, 1996; Mulligan, 1988)

\section{The disadvantages of life maps}

- The fixed themes could limit the individual's self-expression.

- Adults may show resistance to drawing life maps.

- Life maps could be time consuming.

- Individuals may find it difficult to draw life maps unless a comfortable therapeutic relationship exists.

- Painful memories may be revived and this process needs efficient therapeutic input.

(Backhaus, 1984; Mulligan, 1988)

\section{APPLICATION OF THE TECHNIQUE IN A SOCIAL GROUP WORK PROGRAMME FOR YOUNG ADULTS LIVING WITH HIV/AIDS}

Social group work was the method of choice for this programme as it offers the young person living with HIV/AIDS the opportunity to relate to others, to enhance awareness, to form identity, and it is cost and time effective. Getzer (1994) identified relevant topics for group discussions with persons living with HIV/AIDS. The life map, associated with the topics and the group process, forms the basis of the social group work programme (Figure 2). 
FIGURE 2

LIFE MAPS AND THE GROUP WORK PROCESS

\begin{tabular}{|c|c|c|c|}
\hline $\begin{array}{l}\text { PHASE OF THE } \\
\text { GROUP WORK } \\
\text { PROCESS }\end{array}$ & $\begin{array}{l}\text { GOALS AND } \\
\text { OBJECTIVES }\end{array}$ & $\begin{array}{l}\text { SUGGESTED } \\
\text { THEMES }\end{array}$ & ACTIVITIES \\
\hline $\begin{array}{l}\text { PREPARATION/- } \\
\text { PRE-GROUP } \\
\text { PHASE }\end{array}$ & $\begin{array}{l}\text { Orientation } \\
\text { Building } \\
\text { relationships } \\
\text { Establishing } \\
\text { commitment } \\
\text { Measurement } \\
\end{array}$ & $\begin{array}{l}\text { Motivational session to } \\
\text { introduce the programme } \\
\text { Individual preparation of } \\
\text { group members }\end{array}$ & $\begin{array}{l}\text { Needs assessment } \\
\text { questionnaire } \\
\text { Pre-testing } \\
\text { Individual preparation of } \\
\text { group members }\end{array}$ \\
\hline $\begin{array}{l}\text { THE INITIAL } \\
\text { PHASE }\end{array}$ & $\begin{array}{l}\text { Initial observation, } \\
\text { overcoming uncer- } \\
\text { tainties, defining } \\
\text { objectives and } \\
\text { motivation of } \\
\text { group members } \\
\end{array}$ & $\begin{array}{l}\text { Role clarification } \\
\text { Sharing of expectations }\end{array}$ & $\begin{array}{l}\text { Ice breaker } \\
\text { Contracting }\end{array}$ \\
\hline $\begin{array}{l}\text { THE TRANSITION } \\
\text { PHASE }\end{array}$ & $\begin{array}{l}\text { Mutual trust and } \\
\text { responsibility }\end{array}$ & $\begin{array}{l}\text { Sharing of personal } \\
\text { narratives } \\
\text { Exploring the roles of } \\
\text { family members, friends } \\
\text { and society } \\
\text { Exploring past } \\
\text { experiences } \\
\text { Exploring quality of life } \\
\text { options }\end{array}$ & $\begin{array}{l}\text { Life maps 1-3 } \\
\text { Personal label worksheet } \\
\text { Your lifeline worksheet } \\
\text { Philosophy for life } \\
\text { worksheet }\end{array}$ \\
\hline $\begin{array}{l}\text { THE WORKING } \\
\text { STAGE }\end{array}$ & $\begin{array}{l}\text { Cohesion, inti- } \\
\text { macy, participa- } \\
\text { tion, interaction } \\
\text { and commitment }\end{array}$ & $\begin{array}{l}\text { Exploring coping skills } \\
\text { Finding practical ways to } \\
\text { live hopefully day-by- } \\
\text { day } \\
\text { Finding ways to give and } \\
\text { accept support, } \\
\text { Constructing a personal } \\
\text { belief system, } \\
\text { Problem solving } \\
\text { activities }\end{array}$ & $\begin{array}{l}\text { Life maps } 4-6 \\
\text { Problem solving worksheet } \\
\text { Personal goals worksheet } \\
\text { Resource application } \\
\text { worksheet }\end{array}$ \\
\hline THE FINAL STAGE & $\begin{array}{l}\text { More independence } \\
\text { and less } \\
\text { commitment to the } \\
\text { group }\end{array}$ & $\begin{array}{l}\text { Taking responsibility for } \\
\text { one's own life and health } \\
\text { Dealing with issues of } \\
\text { separation and loss }\end{array}$ & $\begin{array}{l}\text { Life map } 7 \\
\text { Imaginary tombstone } \\
\text { worksheet } \\
\text { Candle-lit ceremony } \\
\text { Quilt-making exercises } \\
\end{array}$ \\
\hline $\begin{array}{l}\text { THE POST-GROUP } \\
\text { PHASE }\end{array}$ & $\begin{array}{l}\text { Individual follow- } \\
\text { up } \\
\text { Evaluation } \\
\text { Measurement }\end{array}$ & $\begin{array}{l}\text { Individual coping } \\
\text { (without the group) }\end{array}$ & $\begin{array}{l}\text { Personal quilts for group } \\
\text { members } \\
\text { Post-testing } \\
\text { Evaluation questionnaire }\end{array}$ \\
\hline
\end{tabular}

(Herbst, 2002) 
250

The following schedule structured every group session:

- Introduction to the life map;

- Discussion of the aims and objectives;

- Supplying applicable materials and equipment (worksheets, drawing material, glue, scissors, magazines);

- The time schedule;

- Specific instructions;

- Sharing of life maps;

- Discussion;

- Summary;

- Action and homework.

\section{EVALUATION OF THE PROGRAMME}

\section{Research methodology}

The study was divided into two phases and in each phase a different research design was applied. In the first phase, where a needs assessment was done, the exploratory research design was applied (Fouche \& De Vos, 2005; Rubin \& Babbie, 2001). This design was chosen because an existing phenomenon was further explored and described in order to identify the needs and to supply answers on how young adults' general contentment was affected by HIV/AIDS. The results of the first phase of this study were published in another article. The second phase, during which the group work programme was developed and evaluated, is the focus of this article. In this phase the explanatory research design was applied. This design is especially applicable where limited information is available on a subject and it may involve comparison groups or social experiments that could assist social workers to develop new treatment approaches (Royse, 1995). As a technique, life maps are fairly unknown in social work practice, and in this study experimental research was applied to compare a group in which life maps were applied with another group in which life maps were not applied.

As the aim of this study was to develop an innovative intervention strategy, the intervention research model was applied involving both qualitative and quantitative methods. Intervention research is described as applied research with a specific intervention mission (Thomas \& Rothman, 1994). The intervention research model (Thomas \& Rothman, 1994) was applied and evaluation was conducted by means of the classic experiment (Monette, Sullivan \& De Jong, 2005). Experimental research can be seen as highly scientific and one of the best ways to measure causality between a treatment programme and expected outcome (Powers, Meenaghan \& Toomey, 1985); it regularly applied in explanatory research (Grinnell \& Williams, 1990) and can be successful in the study of small group interaction (Babbie, 2001). This matches the basic aim of this study to determine whether or not the application of life maps in a group work programme will change the general contentment of a small group of young adults living with HIV/AIDS.

\section{Introduction to the groups involved in the experiment}

The population consisted of 20 young adults living with HIV/AIDS, selected by target sampling. They completed a needs assessment questionnaire. Target sampling is defined by Strydom and De Vos (2005:203) as "a purposeful, systematic method by which controlled lists of specified populations within geographical districts are developed and detailed plans are designed to recruit 
adequate numbers of cases within each of the targets. For the purpose of this study, the following targets were set to identify respondents to be included in the experiment:

- Respondents who indicated a willingness to further participate in the needs assessment;

- Respondents living in the Bloemfontein geographical area;

- An equal age and gender distribution for both the experimental and the control groups.

Initially the experimental group consisted of ten young adults living with HIV/AIDS and who indicated a willingness to participate in a group situation. This group participated in the pre-test, the group work programme and the post-test. The control group also consisted of ten young adults living with HIV/AIDS, but they only participated in the pre- and the post-tests. After one member of the experimental group had withdrawn, only nine group members participated in both groups. The control group consisted of respondents who were willing to contribute towards the study, but not in the group work programme, because they were not comfortable with disclosing their HIV status, or lived outside the specified geographical area.

\section{Measuring instrument}

The Generalised Contentment Scale [GCS], one of the WALMYR Assessment Scales [WAS] (Bloom, Fischer \& Orme, 1999), was administered in pre- and post-testing. The GCS is designed to measure the way one feels about one's life and surroundings. It is a generalised measuring instrument that consists of 25 items and applying a 7-point scale, ranging from $1=$ none of the time, to $7=$ all of the time to each question. The GCS is highly recommended to monitor clients during intervention through periodic administration of the same questionnaire (Bloom et al., 1999). In this study the aim of administering the GCS was to determine respondents' general contentment with life and to use the data for pre- and post-testing purposes. The GCS was administered before intervention to gather baseline information and after intervention to determine whether or not the intervention programme had any impact on the respondents' contentment. Ultimately, the objective was to determine a link between the respondents' general contentment and the application of life maps as technique. To establish triangulation, the experimental group also completed a self-developed evaluation questionnaire and participated in an evaluation group session after the intervention programme. All the WAS are scored in the same way, utilising reverse-scored items to limit response set bias (Bloom et al., 1999). Data were analysed using computer software of the Perspective Training College (PASWIN, 2000). The software is designed to conduct the scoring and interpretation of data by supplying scores for every individual as well as a group profile. After scoring, PASWIN (2000) supplies the scores ranging from $0-100 \%$ and an interpretation regarding the following values:

- A score of more than $\mathbf{3 5 \%}$ indicates a need for improvement in certain areas;

- A score between $\mathbf{2 5 \%}$ and $\mathbf{3 5 \%}$ indicates a warning that an area needs attention;

- A score below $\mathbf{2 5 \%}$ falls within the recommended range.

Bloom et al. (1999) refer to a score of approximately 30 as the clinical cutting score in all the WAS, indicating that people may experience problems in areas with a score higher than 30 . The specific areas that need improvement are indicated in the interpretation supplied by PASWIN (2000). All the WAS have a high validity and reliability, but as is the case for all measuring instruments, there may still be some degree of inaccuracy (Bloom et al., 1999). The standard error in measurement and triangulation was used to increase validity and reliability. 


\section{Pre-testing}

Both the experimental and control groups completed the GCS before presentation of the Thsepang Programme. The following table presents the individual and group pre-test scores.

TABLE 1

PRE-TEST SCORES

\begin{tabular}{|c|c|c|c|}
\hline \multicolumn{2}{|c|}{ EXPERIMENTAL GROUP } & \multicolumn{2}{|l|}{ CONTROL GROUP } \\
\hline $\begin{array}{c}\text { RESPONDENT } \\
1\end{array}$ & $\begin{array}{c}\text { GCS } \\
\text { SCORE } \\
59 \%\end{array}$ & $\begin{array}{c}\text { RESPONDENT } \\
1\end{array}$ & $\begin{array}{c}\text { GCS } \\
\text { SCORE } \\
49 \%\end{array}$ \\
\hline 2 & $62 \%$ & 2 & $16 \%$ \\
\hline 3 & $48 \%$ & 3 & $70 \%$ \\
\hline 4 & $26 \%$ & 4 & $58 \%$ \\
\hline 5 & $16 \%$ & 5 & $20 \%$ \\
\hline 6 & $42 \%$ & 6 & $44 \%$ \\
\hline 7 & $8 \%$ & 7 & $30 \%$ \\
\hline 8 & $48 \%$ & 8 & $43 \%$ \\
\hline 9 & $23 \%$ & 9 & $25 \%$ \\
\hline AVERAGE SCORE OF GROUP & $36.9 \%$ & AVERAGE SCORE OF GROUP & $39.4 \%$ \\
\hline
\end{tabular}

The scores were interpreted according to the score ranges described earlier, indicating that both groups' GCS scores were above the recommended range of $25 \%$ and indicated a need for improvement. The experimental group's scores were slightly $(2.5 \%)$ lower than those of the control group. In the group summary profile which was compiled by means of Perspective Training College Software (Paswin, 2000), it was indicated that the following areas needed attention in both groups:

- Powerlessness to do anything about their lives;

- Feelings of sadness and crying spells;

- Depression;

- Difficulty to get started with the things they had to do.

\section{Data analysis}

The data collected were mainly qualitative and were analysed by following Tesch's approach as described by Poggenpoel (1998). Tesch's approach involves the following eights steps.

1. Review all collected data by reading through it carefully and jot down ideas at random.

2. One respondent's data which is of particular interest or is the shortest, etc., should be selected, and the following question asked: What is this all about? The researcher's own thoughts concerning the underlying meaning of the information are subsequently written down. 
3. The same procedure should be followed for several respondents. The researcher then starts to combine similar themes and makes a list of topics. These topics are then clustered into columns and might be arranged into major topics, unique topics and leftovers.

4. Topics should be abbreviated as codes and reverted to the text. This needs to be done to see whether or not new categories and codes emerge.

5. Descriptive wording must be selected for the different topics and lines are drawn between the categories to show interrelationships.

6. A final decision is made on the abbreviation of each category and codes are arranged in alphabetical order.

7. Similar data material is assembled and a preliminary analysis is performed.

8. Existing data should be recoded if necessary.

Analysed data were presented to the group during the evaluation and post-test phase of the study in an attempt to increase the trustworthiness of the data. Respondents had the opportunity to reflect upon the themes, ask questions and make suggestions. Methodological triangulation (De Vos, 2005) was established through standardised measurement, a self-developed evaluation questionnaire and group interviewing.

\section{EVALUATION OF THE PROGRAMME}

The following is a description of every group session in terms of aims, contents, evaluation and data collected.

\section{SESSION 1: INTRODUCTION, MEASUREMENT AND PREPARATION}

AIMS: The aims of this session were orientation, building relationships, establishing commitment and measuring (pre-testing).

CONTENTS: The group leader, group members and programme were introduced, mutual expectations were shared and the rules of the group were set. The group members were requested to complete the GCS. The name of the group, Thsepang Workshop, was discussed as initial topic, resulting in interesting comments. There was a remarkably positive attitude among group members towards their HIV status. They expressed a wish to make the most of their lives, notwithstanding the fact that they were living with a life-threatening disease. Most of the group members were interested in the approach of not receiving lectures, but a focus on self-disclosure and self-development in a supportive environment.

EVALUATION: The respondents were excited and looked forward to the actual contents of the programme. Communication occurred freely because six of the members knew each other from a previous support group. Bonding took place and commitment was established.

DATA COLLECTED: Pre-test GCS results indicated a general contentment with life of $36.9 \%$. This score is higher than $35 \%$, which indicated a need for improvement according to the interpretation of the scale.

\section{SESSION 2: LIFE MAP 1 - WHO AM I?}

AIM: To offer group members the opportunity to establish identity by exploring and expressing the self.

CONTENTS: The group members were introduced to Life Map 1 as a tool to promote selfawareness, self-expression and identity. The appropriate worksheets were supplied and group members were requested to creatively express who they were. They were reassured that they did not have to produce works of art, but works of heart. They worked enthusiastically and, after completion, they described their life maps, sharing only what they felt comfortable with. This was 
followed by a group discussion, including themes such as personal beliefs, work situation, position in the family, personality traits, educational situation and personal dreams. To conclude the session, group members were requested to complete worksheets on which they listed their strengths and weaknesses. Most of the group members perceived their optimistic approach to living with HIV/AIDS as a win-win situation.

EVALUATION: The group members enjoyed drawing and magazine photo collages on the first life map theme. At first they found sharing their life maps difficult, but it became easier after the researcher had shared her life map, giving the group members an idea of how to go about it. Communication gradually occurred more freely as uncertainties were overcome and cohesion grew.

DATA COLLECTED: Three main themes were identified: descriptions related to family and sex role; health, energy and HIV status; and identity and personal desires. From these data it seemed that the overall identity of the group members focused on the role of HIV/AIDS, their primary roles in life, education and a meaningful life.

\section{SESSION 3: LIFE MAP 2 - WHERE HAVE I COME FROM?}

AIM: To gain an overview of group members' individual backgrounds and pasts and determine the influence of their backgrounds on their current life situation.

CONTENTS: Life Map 2 was introduced by emphasising the role of personal history and roots in the lives of human beings. Applicable worksheets were handed out and group members were allowed to illustrate their life maps by using drawings or magazine photo collages. During the description of their life maps several group members became very emotional. Two of them described the loss of primary family members to HIV/AIDS, one relived the burning down of their house, and another described his intense loneliness and isolation. The latter group member said that his total social system consisted of his mother and his dog. Group members really supported each other in a very compassionate manner, and group cohesion, intimacy and interaction increased dramatically. The session lasted for longer than two hours, but served as a very necessary catharsis. Various group members expressed the positive value of being in a group of people with similar experiences and problems, where they had the opportunity to express their feelings freely. One of the topics discussed included the question of what they would have liked to change about their lives. Most of them wanted their lives just the way they were, but two wished they could change the past. One wished that her husband and child, who had died of AIDS, were still alive and the other, a sex worker, wanted to change her lifestyle. Themes of discussion included birth, childhood, education, HIV diagnosis and implications. The discussion of lifelines resulted in another session of mutual support and encouragement. Some of the following phrases were used to give encouragement and are used in this paper with the permission of the group members:

- "I am still healthy, six years after I was diagnosed with HIV" and "HIV is not only for Human Immune deficiency Virus, but also for Hope Is Vital” - Mathilda. ${ }^{1}$

- "Life is still surprisingly beautiful” - Debrah.

- "My body is carrying the HI- virus, but I am spiritually healed" - Boithetelo.

- "I am not dying of AIDS, I am living with it" - George.

\footnotetext{
${ }^{1}$ Names of actual participants are used with their informed, written consent.
} 
EVALUATION: This was a very emotional session, resulting in increased cohesion, intimacy and mutual support. The opportunity for emotional catharsis was very important and group members gained a lot in sharing in one another's pain and suffering of the past. They were guided to acknowledge the impact of the past, work through unresolved issues and to accept the things they could not change. For many group members this was the first opportunity to share their pain and sorrow and it seemed a relief to them.

DATA COLLECTED: The central themes of this group session were family of origin, education, housing and financial situation, and health status. Some of the traumas of the past included early pregnancies, deaths in their primary families, divorce, poverty, prostitution and rape.

\section{SESSION 4: LIFE MAP 3 - WHERE AM I GOING?}

AIM: To enable group members to find a vision and direction for their lives by determining their personal beliefs and values.

CONTENTS: Group members were instructed to illustrate Life Map 3. They enjoyed visualising their dreams and goals - some realistic and some probably bound to be dreams forever. A positive and energetic discussion followed. Their future dreams and goals consisted mainly of obtaining education, establishing a family, living positively with HIV/AIDS, spiritual growth and financial security. The session was concluded with the group members writing their personal philosophies for their lives. The concept philosophy was explained to them as their own bill of rights, their own values and beliefs, their own views of life and their personal opinion on how to achieve their personal goals.

EVALUATION: This session was full of energy, optimism and hope for the future. Group members started to show responsibility for their own lives, enjoyed writing their philosophies and experienced it very positively when the researcher had each philosophy typed and formally presented to them as a keepsake. The goal of giving them a vision for the future was definitely achieved.

DATA COLLECTED: The central themes of this group session were education, career possibilities, financial security, living positively with HIV/AIDS, marriage and family life, spiritual growth and contentment with life.

SESSION 5: LIFE MAP 4 - WHAT IS STOPPING ME?

AIMS: The first aim of this session was to identify the internal and external obstacles that limited the group members' personal and social growth and prevented them from achieving their personal goals. The second aim was to teach group members some problem-solving skills.

CONTENTS: The session started with the drawing of Life Map 4 and was followed by an honest and spontaneous discussion. Group members did introspection and were able to identify certain obstacles in their lives, including limited time, lack of resources and the impact of HIV/AIDS. One of the group members died shortly after the Thsepang Workshop in a tragic shooting incident. The following words were written on her fourth life map:

"I need only time power to make all the things to fulfil my dreams. I need time. Only time will allow me! Yesterday I said I think too much within a limited space of time. Definitely going to fulfil my dreams. Energy is wanted!"

Group members reflected upon their temperaments and personality traits as obstacles that affected their achievement of certain goals. One group member mentioned impatience and anger as two limitations, while another felt that poverty and limited opportunities were his biggest obstacles. They were guided to prioritise their obstacles/problems and to utilise the problem-solving 
cycle to try and overcome certain problems. Small toy dustbins were handed out to each group member. They were instructed to literally throw away problems that could not be solved and that wasted their time and energy. They enjoyed this activity tremendously and their feedback was that the action of throwing away certain problems brought emotional relief and perspective. Increased responsibility was observed and group members were committed to working actively at their problems. They were interested in the problem-solving cycle as a tool to implement practically in their lives.

EVALUATION: It was observed that group members were empowered by seeing their problems in a black and white context, giving them control and seeing the problem-solving cycle placing their obstacles in perspective. The profound sense of responsibility and commitment was positive.

DATA COLLECTED: Obstacles in the lives of the group members were mainly associated with HIV/AIDS, followed by limited resources and support and lack of education.

\section{SESSION 6: LIFE MAP 5 - HOW WILL I GET THERE?}

AIM: To actively involve group members in planning and implementing strategies to achieve their life goals.

CONTENTS: Group members made drawings to illustrate Life Map 5. This life map seemed to be a challenge and group members worked independently at describing their personal plans of action. Two members said that their feelings of helplessness and hopelessness were obstacles to formulating a plan for their lives. The other group members reflected personal commitment and tried to positively influence the reluctant group members. Sharing of the life maps was done with excitement and the group members presented their life plans with pride and concrete action plans to realise their dreams and goals. Most of the plans were illustrated in the form of steps or ladders.

EVALUATION: The practical impact of this session was evaluated positively and members' active participation confirmed that they were able to take responsibility for their lives, and that they were inspired to do something with their lives. It seemed that insight into their strengths and weaknesses increased and they were able to set realistic goals.

DATA COLLECTED: The data were of an individual and more personal nature, but a number of central themes could be identified, including further education, living a meaningful life, managing HIV, overcoming financial and psycho-social obstacles and obtaining support. Although HIV/AIDS formed part of the central themes, the themes correlated with the expected developmental goals of the young adult.

SESSION 7: LIFE MAP 6 - WHAT HELP DO I NEED?

AIM: To facilitate the group in identifying and utilising available resources to put their plans into action.

CONTENTS: Life Map 6 was drawn rather quickly and the descriptions involved both emotional and practical aspects. Discussions centred on access to resources, including schools and tertiary institutions, health care facilities, social support systems and religious and financial institutions. Group members were assisted in writing a resource application letter in order to teach them the skill of writing a business letter. They were also assisted in using a telephone directory to obtain the contact details of necessary community and other resources. Bloemfontein ATICC supplied each group member with a comprehensive guide on HIV/AIDS-related resources, which would enable group members to choose services they needed, but also to identify organisations they could become involved in as volunteers. Some of these organisations, such as The Young Living Ambassadors Project, actually employed young adults living with HIV/AIDS. This session also 
involved an emotional discussion on how much the family is needed as a resource. One member was rejected by her family due to her life as sex worker. The group members motivated her to write a letter to her parents to describe her emotions and needs, and to tell them that she had decided to change her life.

EVALUATION: The aim of enabling group members to identify and utilise resources was achieved by teaching them how to approach potential resources. Although many needed practical help, the emotional component was not ignored, emphasising the important role of family and friends as resources in the lives of young persons living with HIV/AIDS.

DATA COLLECTED: Data collected by means of Life Map 6 indicated the following categories of resources needed by the group members: financial institutions; health care facilities; personal resources (human capital); religious institutions; social systems (family and friends); and educational facilities. The group members prioritised the resources and indicated that social support, health care facilities and religious institutions are the most needed resources.

\section{SESSION 8: LIFE MAP 7- WHAT WILL IT BE LIKE WHEN I GET THERE?}

AIM: To guide group members to form a clear image of what they were aiming at in their lives and to summarise their previous life maps.

CONTENTS: Group members drew optimistic pictures of the pieces of their lives coming together to form a total picture. The discussion that followed was a mixture of optimism and realism. They expressed their hopes for the future, on the one hand, wishing that their dreams and plans would be realised, but they were still aware of obstacles and the realities of their lives. One group member emphasised the fact that people living with HIV/AIDS should be considered normal people, with the same needs, dreams, abilities and emotions as anybody else. Family life, sexual relationships and mortality were the main themes of discussion.

EVALUATION: This session was full of emotion and realism. Group members expressed their hopes for the future, but were also realistic about their lives and their HIV status. Emphasis was not placed upon HIV/AIDS alone, but on being human. The life maps were summarised and group members were guided into the final stage of the group work series.

DATA COLLECTED: The central themes that could be identified from this map included death as possible outcome of HIV/AIDS, the family system as valuable asset, the importance of safe sex, the importance of a message of hope and the fact that a positive attitude towards living with HIV/AIDS is essential.

SESSION 9: SUMMARY, CLOSURE AND EVALUATION

AIM: To summarise, evaluate and conclude the group series.

CONTENTS: This was a marathon group session of almost six hours. An evaluation questionnaire was completed, a quilt was painted to summarise the group series, the group shared a meal together and a candle-lighting ceremony served as formal closing ritual.

EVALUATION: The activities in the final session involved creativity, fun, socialisation and respect. The quilts reflected the group's awareness of the impact of HIV/AIDS on their lives, but it clearly included a message of hope. This session gave the group members the opportunity to summarise their experiences and to conclude the process in an appropriate way. The formal evaluation ensured valuable feedback.

DATA COLLECTED: From the evaluation questionnaire, it was clear that all the group members had gained something positive from the programme. They rated acquiring hope and gaining self-knowledge as the most valuable part of the programme. Life Map 4 What is stopping 
me? was identified as the most interesting part of the programme and helped group members to make the necessary changes in their lives. One group member experienced the extent of personal disclosure in the group as negative.

\section{POST-TESTING}

Post-testing was conducted six weeks after the group work programme had been presented. Both the experimental and control groups completed another GCS. The average score of the experimental group was $26.2 \%$, while the average score of the control group was $40.7 \%$. The experimental group's general contentment measured almost within the recommended range (below 25\%), while the control group's general contentment score of more than $35 \%$ indicated a need for improvement. A comparison between the pre- en post-test results is provided in Table 2 . Upon comparing the pre- and post-test results, it is evident that the general contentment of the experimental group members increased by $10.7 \%$ after the group work programme. The control group's general contentment score increased by $1.3 \%$, indicating a score that needs attention.

TABLE 2

POST-TEST RESULTS

\begin{tabular}{|c|c|c|c|}
\hline \multicolumn{2}{|c|}{ EXPERIMENTAL GROUP } & \multicolumn{2}{c|}{ CONTROL GROUP } \\
\hline AVERAGE & AVERAGE & AVERAGE & AVERAGE \\
PRE-TEST SCORE & POST-TEST SCORE & PRE-TEST SCORE & POST-TEST SCORE \\
\hline $\mathbf{3 6 . 9 \%}$ & $\mathbf{2 6 . 2 \%}$ & $\mathbf{3 9 . 4 \%}$ & $\mathbf{4 0 . 7 \%}$ \\
\hline
\end{tabular}

\section{SYNTHESIS OF MAJOR FINDINGS AND CONCLUSIONS}

The data gathered in this study have emphasised the need for social work programmes to support the thousands of people living with HIV/AIDS. Because young adults are amongst those who are most affected by HIV/AIDS, programmes need to focus on the specific tasks of this developmental stage. Social group work can be effectively applied in HIV/AIDS support programmes and the life map technique can structure the group process. Aspects that may be addressed through the application of life maps include identity formation, self-determination, personal responsibility, overcoming fears, obstacles and confusion, dealing with loss, utilising resources, emotional disclosure, gaining control, problem-solving and obtaining a vision for life. The life map technique has certain limitations, but it offers various creative and therapeutic opportunities for the social work practitioner.

This programme was evaluated by both quantitative and qualitative measurements and has proven an effective programme to increase the general contentment of a group. The group members' overall evaluation of the programme was that it offered a positive growth and learning opportunity, where self-discovery was valuable in terms of identity formation, problem-solving, resolving personal issues and establishing hope for the future.

\section{RECOMMENDATIONS}

Although this group work programme has the potential to be incorporated into existing support programmes for persons living with HIV/AIDS, applying the life map technique is not limited to social work in the field of HIV/Aids. The technique is applicable to basically all fields of service where identity issues need to be resolved, problem solving must take place, or the past, present and future need integration. Applying the technique in practice has therapeutic and developmental value, but the intensity of self-discovery and disclosure can be very intense, and practitioners must be prepared to deal with the emotions and reactions in a professional and sensitive manner. 


\section{REFERENCES}

BABBIE, E. 2001. The practice of social research $\left(9^{\text {th }}\right.$ ed). Belmont, CA: Wadsworth/Thomson. BACKHAUS, K.A. 1984. Life books: Tools for working with children in placement. Journal of the National Association of Social Workers, 29(6):551-554.

BARKER, R.L. 2003. The Social Work Dictionary $\left(5^{\text {th }}\right.$ ed). Silver Spring: NASW Press.

BIGGS, D.A. 1994. Dictionary of Counselling. Westport: Greenwood Press.

BLOOM, M., FISCHER, J. \& ORME, J.G. 1999. Evaluating practice: Guidelines for the accountable professional. Needham Heights: Allyn \& Bacon.

CLARKSON, P. \& MACKEWN, J. 1993. Fritz Perls. London: SAGE Publications.

COREY, G. 1995. Theory and practice of group counselling $\left(4^{\text {th }}\right.$ ed $)$. Pacific Grove: Brooks/Cole.

DE VOS, A.S. 2005. Combined quantitative and qualitative approach. In: DE VOS, A.S. (ed) Research at grass roots: For the social sciences and human service professions $\left(3^{\text {rd }} \mathrm{ed}\right)$. Pretoria: Van Schaik.

DULWICH CENTRE. 2002. Narrative Therapy. [Web:] Available: http://www.massey.ac.nz [Rev. 21 January 2006].

FOUCHE, C.B. \& DE VOS, A.S. 2005. Intervention research. In: DE VOS, A.S. (ed) Research at grass roots: For the social sciences and human service professions $\left(2^{\text {nd }}\right.$ ed $)$. Pretoria: Van Schaik.

GETZER, G.S. 1994. No one is alone - groups during the AIDS Pandemic. In: GITTERMAN, A. \& SHULMAN, L. (eds) Mutual aid groups, vulnerable populations and the life cycle $\left(2^{\text {nd }}\right.$ ed). Chichester: Columbia University Press.

GILLIAND, B.E., JAMES, R.K., ROBERTS, G.T. \& BOWMAN, J.T. 1984. Theories and strategies in counselling and psychotherapy. Englewood Cliffs: Prentice-Hall.

GRINNELL, R.M. \& WILLIAMS, M. 1990. Research in social work: A primer. Itasca: Peacock.

HEPPNER, M., O'BRIEN, K., HINKELMAN, J. \& HUMPHREY, C. 1994. Shifting the paradigm - the use of creativity in career counselling. Journal of Career Development, 21(2):77-86.

HERBST, A.G. 2002. Life maps as technique in a social group work programme for young adults with HIV/AIDS. Potchefstroom: North West University. (PhD thesis)

HERBST, A. \& DE LA PORTE, A. 2006. Memory work - telling your story through life maps. Pretoria: CB Powell Bible Centre.

JOHNSON, D.W. 1990. Reaching out - interpersonal effectiveness and self-actualization $\left(4^{\text {th }}\right.$ ed). Englewood Cliffs: Prentice-Hall.

LANDGARTEN, H.B. 1993. Magazine photo collage - a multicultural assessment and treatment technique. New York: Brunner/Mazel.

LECKY, W.E.H. 1909. The map of life. London: Longmans \& Green.

McCORMICK, E.W. 1996. Change for the better - self-help through practical psychotherapy. London: Cassell. 
MONETTE, D.R., SULLIVAN, T.J. \& DE JONG, C.R. 2005. Applied social research - tool for the human services $\left(6^{\text {th }}\right.$ ed $)$. Fort Worth: Harcourt Brace College.

MUlligAN, J. 1988. The Personal Management Handbook - how to make the most of your potential. London: Guild.

PASWIN. 2000. Perspective Training College Software. [CD-ROM].

PATEL, L. 2005. Social welfare and social development in South Africa. Cape Town: Oxford University Press.

POGGENPOEL, M. 1998. Data analysis in qualitative research. In: DE VOS, A.S. (ed) Research at grass roots: A primer for the caring professions. Pretoria: Van Schaik.

POWERS, G.T., MEENAGHAN, T.M. \& TOOMEY, B.G. 1985. Practice focused research: Integrating human service practice and research. Englewood Cliffs: Prentice-Hall.

RETIEF, Y. 1999. Lag weer oor die dag wat kom: Briewe aan 'n gemolesteerde. Kaapstad: Struik.

ROYSE, D. 1995. Research methods in social work. Chicago: Nelson-Hall.

RUBIN, A. \& BABBIE, E. 2001. Research methods for social work $\left(4^{\text {th }} \mathrm{ed}\right)$. Belmont, CA: Wadsworth/Thomson.

SHAFFER, J.B.P. \& GALINSKY, M.D. 1989. Models of group therapy. Englewood Cliffs: Prentice-Hall.

SHANTALL, H.M. 1988. Die eksistensiële teorie van Viktor Frankl. In: MEYER, W.F.; MOORE, C. \& VILJOEN, H.G. (eds) Persoonlikheidsteorieë - van Freud tot Frankl. Johannesburg: Lexicon.

STRYDOM, H. \& DE VOS, A.S. 2005. Sampling and sampling methods. In: DE VOS, A.S. (ed) Research at grass roots: For the social sciences and human service professions $\left(3^{\text {rd }}\right.$ ed). Pretoria: Van Schaik.

THOMAS, E.J. \& ROTHMAN, J. 1994. An integrative perspective on intervention research. In: ROTHMAN, J. \& THOMAS, E.J. (eds) Intervention research. Binghamton: Haworth Press.

THOMPSON, C.L. \& RUDOLPH, L.B. 1992. Counseling children $\left(3^{\text {rd }}\right.$ ed). Pacific Grove: Brooks/Cole.

VAN NIEKERK, M. 2003. The unheard stories of adolescents infected and affected by HIV/AIDS about care and/or the lack of care. Practical Theology in SA, 18(3):109-120.

VAN WORMER, K. \& DAVIS, D.R. 2003. Addiction treatment - a strengths perspective. Pacific Grove: Brooks/Cole.

WHITBOURNE, S.K. 1986. The me I know - a study of adult identity. New York: SpringerVerlag.

YOCHANAN, W. 1991. People care in institutions: A conceptual schema and its application. Child \& Youth Services, 15(1):91.

Prof Herman Strydom, Subject Head; Dr Alida Herbst, Senior Lecturer, Social Work Division, School for Psycho-Social Behavioural Sciences, North-West University, Potchefstroom Campus, South Africa. 